\title{
Glycyrrhetinic acid and its derivatives as inhibitors of poly(ADP-ribose)polymerases 1 and 2, apurinic/ apyrimidinic endonuclease 1 and DNA polymerase $\beta$
}

\author{
A. L. Zakharenko, O. V. Salomatina ${ }^{1}$, M. V. Sukhanova, M. M. Kutuzov, \\ E. S. Ilina, S. N. Khodyreva, V. Schreiber ${ }^{2}$ N. F. Salakhutdinov ${ }^{1}$, O. I. Lavrik
}

Novosibirsk Institute of Chemical Biology and Fundamental Medicine, Siberian Branch of the Russian Academy of Sciences 8, Akademika Lavrentieva Ave., Novosibirsk, Russian Federation, 630090

${ }^{1}$ N. N. Vorozhtsov Novosibirsk Institute of Organic Chemistry, Siberian Branch of the Russian Academy of Sciences 9, Akademika Lavrentieva Ave., Novosibirsk, Russian Federation, 630090

${ }^{2}$ UMR7242, University of Strasbourg, CNRS, ESBS

Cedex Illkirch Cedex, France, 67412

lavrik@niboch.nsc.ru; anvar@nioch.nsc.ru

\begin{abstract}
Aim. For strengthening the efficiency of monofunctional alkylating antineoplastic drugs it is important to lower the capacity of base excision repair (BER) system which corrects the majority of DNA damages caused by these reagents. The objective was to create inhibitors of the key BER enzymes (PARP1, PARP2, DNA polymerase $\beta$, and APE1) by the directed modification of glycyrrhetinic acid (GA). Methods. Amides of GA were produced from the GA acetate by formation of the corresponding acyl chloride, amidation with the appropriate amine and subsequent deacylation. Small library of 2-cyano substituted derivatives of GA methyl esters was obtained by the structural modification of GA framework and carboxylic acid group. The inhibitory capacity of the compounds was estimated by comparison of the enzyme activities in specific tests in the presence of compounds versus their absence. Results. None of tested compounds inhibits PARP1 significantly. Unmodified GA and its morpholinic derivative were shown to be weak inhibitors of PARP2. The derivatives of GA containing keto-group in 11 triterpene framework were shown to be moderate inhibitors of pol $\beta$. Compound 3, containing 12-oxo-9(11)-en moiety in the ring $C$, was shown to be a single inhibitor of APE1 among all compounds studied. Conclusions. The class of GA derivatives, selective pol $\beta$ inhibitors, was found out. The selective inhibitor of APE1 and weak selective inhibitor of PARP2 were also revealed.
\end{abstract}

Keywords: DNA polymerase $\beta$, poly(ADP-ribose)polymerases 1 and 2, apurinic/apyrimidinic endonuclease 1 , glycyrrhetinic acid, inhibitor.

Introduction. Alkylating reagents being the oldest class of anticancer drugs are still commonly used; they play an important role in the treatment of several types of cancer. Alkylated bases are predominantly removed by base excision repair (BER) [1]. Apurinic/apyrimidinic endonuclease 1 (APE1) and DNA polymerase $\beta$ (pol $\beta$ ) involved in processing of apurinic/ apyrimidinic sites and DNA synthesis, the common stages of BER independent on type of base damage,

C Institute of Molecular Biology and Genetics, NAS of Ukraine, 2012 can be considered as the most relevant targets. For targeting the whole BER process an alternative approach can be used. It is based on the inhibition of proteins, which regulate the overall efficiency of BER. Poly(ADPribose)polymerases 1 and 2, PARP1 and PARP2, respectively, are considered as regulators of BER [2]. Several PARP inhibitors in combination with an alkylating drug, temozolomide, are included in current clinical trials [3].

Thus, specific targeting BER enzymes, catalyzing the key stages, in combination with alkylating reagents is considered as a perspective approach in cancer therapy. 
Glycyrrhetinic acid (GA) possesses a broad spectrum of pharmacological activities and serves as a base for highly active drug preparations [4, 5]. GA is an aglycone of glycyrrhizic acid obtained from the roots of licorice plants and represents the main product of its metabolism $[4,5]$. In the two past decades, there has been growing interest in the study of licorice, one of the most ancient medicinal plants that were widely used in Chinese and Tibetian medicine.

The renewed interest in licorice reflects the general trend observed in medicinal practice, where remedies of natural origin are finding increasing application despite considerable success in the use of many synthetic drugs. The drug preparations based on modified natural compounds frequently exceed the parent substances in activity. For instance, several GA derivatives display considerable antitumor activity [6-8].

Modulation of BER has the potential to enhance response to chemotherapy and improve outcomes in tumor treatment. In the current study, we aimed to study inhibitory properties of GA derivatives on key BER proteins, PARP1, PARP2, APE1 and pol $\beta$, which are considered as targets in cancer therapy.

Materials and methods. Materials. Rainbow molecular mass markers («Amersham», USA) and the main components of buffers, $\beta-\mathrm{NAD}^{+}$(«Sigma», USA; or Russian, ultrapure grade). 18ßH-Glycyrrhetinic acid acetate obtained from a licorice extract was used as a starting material (purity $294 \%$ ) [9].

Synthesis of GA derivatives. Methyl-2-cyano-3,11dioxo-18ßH-olean-12(13)-en-30-oate (1) was synthesized according to described method [10]. Methyl-2-cyano-3,11-dioxoolean-1(2),12(13),18(19)-trien-30-oate (2) and methyl-2-cyano-3,12,19-trioxoolean-1(2),11 (9),13(19)-trien-30-oate (4) was synthesized according to [11]. Methyl-2-cyano-3,12-dioxoolean-1(2),11(9)dien-30-oate (3) was synthesized according to [6].

Synthesis of 18BH-GA-30-oic acid amides (5-7). Amides of GA 5-7 were produced from the GA acetate by formation of the corresponding acyl chloride (oxalyl chloride), amidation with the appropriate amine and subsequent deacylation ( $\mathrm{KOH}, \mathrm{MeOH}$-tetrahydrofuran).

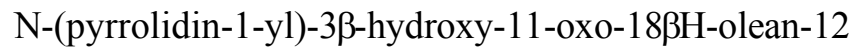
(13)-en-30-oic acid amide (5) was synthesized according to general method with yield $42 \%$. N-(piperidin-

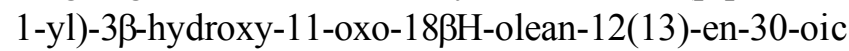

acid amide (6) was synthesized according to general method with yield $30 \%$. N-(morpholino-4-yl)-3ß-hydroxy11-oxo-18ßH-olean-12(13)-en-30-oic acid amide (7) was synthesized according to general method with yield $20 \%$.

Physicochemical description (Mp, ${ }^{1} \mathrm{H}$ and ${ }^{13} \mathrm{C}$ data) of amides 5-7 are in agreement with literature data [12].

Enzymes and their activity tests. Human PARP1, rat pol $\beta$ and human APE1 were expressed in Escherichia coli cells and isolated as described in [13-15], respectively. Murine PARP2 was expressed in insect cells and purified according to [16]. Pol $\beta$, PARP1, and PARP2 activity assays were carried out as described $[14,17,18]$, respectively. APE1 activity assay was carried out essentially as described in [15].

Estimation of the inhibitory characteristics of compounds. The inhibitory capacity of the compounds was estimated by comparison of the enzyme activities in specific tests in the presence of compounds at variable concentrations versus their absence. The concentration of potential inhibitors was varied in the range from $100 \mathrm{nM}$ to $1 \mathrm{mM}$. Depending on properties of tested compounds (solubility in DMSO) and enzyme, we used two types of inhibitory characteristics: residual activity at fixed concentration of compounds or $\mathrm{IC}_{50}$ values (inhibitor concentration reducing the enzyme activity by half).

Results and discussion. Influence of GA derivatives on poly(ADP-ribose) (PAR) synthesis catalyzed by PARP1 and PARP2. PARP1 and PARP2 are molecular sensors of DNA breaks. Their activity is efficiently stimulated by DNA lesions [19]. Involvement of both PARPs in regulation of response to genoxic stress caused by ionizing radiation and alkylating reagents was proved in cells and animal models [19]. Catalytic domains of PARP1 and PARP2 display high level of homology and therefore can efficiently recognize the same compounds-inhibitors [20]. While, there are structural differences (small insertion in PARP2), which are considered as a basis for creation of selective PARP2 inhibitors [21].

Influence of GA derivatives at different concentration of compounds on PARPs activity was determined at linear part of the dependence of the rate of PAR synthesis versus $\mathrm{NAD}^{+}$concentration. Data for all compounds are summarized in Table and Fig 1. Typical curve for PAR synthesis catalyzed by PARP 2 in the presence of GA is shown in Fig. 2. 
Inhibitory characteristics of compounds in specific reactions catalyzed by PARP1, PARP2, DNA polymerase $\beta$ and APE1 (see Figure)

\begin{tabular}{c|c|c|c|c}
\hline Designation & $\begin{array}{c}\text { PARP1 resi- } \\
\text { dual activity, } \\
\text { \%* at 1 mM } \\
\text { inhibitor }\end{array}$ & $\begin{array}{c}\text { PARP2 resi- } \\
\text { dual activity, } \\
\%^{*} \text { at } 1 \mathrm{mM} \\
\text { inhibitor }\end{array}$ & $\begin{array}{c}\text { Influence on } \\
\text { DNA poly- } \\
\text { merase } \beta \\
\text { activity* } \\
\mathrm{IC}_{50}, \mathrm{mM}\end{array}$ & $\begin{array}{c}\text { APE1 residu- } \\
\text { al activity, \%* } \\
\text { at } 0.1 \mathrm{mM} \\
\text { inhibitor }\end{array}$ \\
\hline $\mathbf{G A}$ & 38 & $0.3 \mathrm{mM}^{* *}$ & $>0.1$ & 100 \\
$\mathbf{1}$ & 59 & 67 & 0.07 & 80 \\
$\mathbf{2}$ & 45 & 65 & 0.06 & 86 \\
$\mathbf{3}$ & 78 & 38 & $>0.1$ & $0.03 \mathrm{mM}^{* *}$ \\
$\mathbf{4}$ & 84 & 42 & $>0.1$ & 77 \\
$\mathbf{5}$ & 56 & 53 & 0.07 & 122 \\
$\mathbf{6}$ & 56 & 37 & 0.06 & 92 \\
$\mathbf{7}$ & 46 & $0.7 \mathrm{mM}^{* *}$ & $>0.1 \mathrm{mM}$ & 98 \\
\hline
\end{tabular}

*Mean of at least two determinations; ${ }^{*} \mathrm{IC}_{50}$. leotide excision repair [27]. Thus pol $\beta$ inhibitors can provide a therapeutic effect, especially in combination with DNA targeted drugs.

All synthesized GA derivatives were tested as potential pol $\beta$ inhibitors. A typical curve of the residual pol $\beta$ activity at variable concentration of 5 is shown in Fig. 3. Data on influence of GA derivatives on pol $\beta$ activity are summarized in Table.

The ester of GA bearing keto group at the 11 position (ring C), $\mathbf{1}$ and $\mathbf{2}$, unlike compounds $\mathbf{3}$ and $\mathbf{4}$ with keto group at the 12 position, significantly affect pol $\beta$ activity. In addition, the inhibitory effect is displayed by pyrrolidine amide $\mathbf{5}$ and pyperidine amide $\mathbf{6}$ unlike the morpholine amide 7 . It should be noticed that the last compound has a mild inhibitory effect on PARP2 activity. In line with our observation, several triterpe-

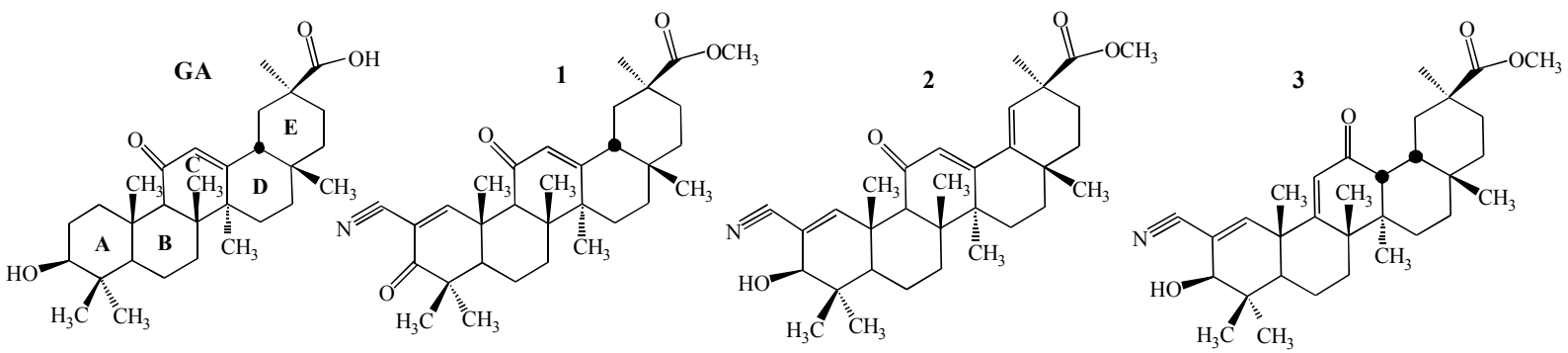

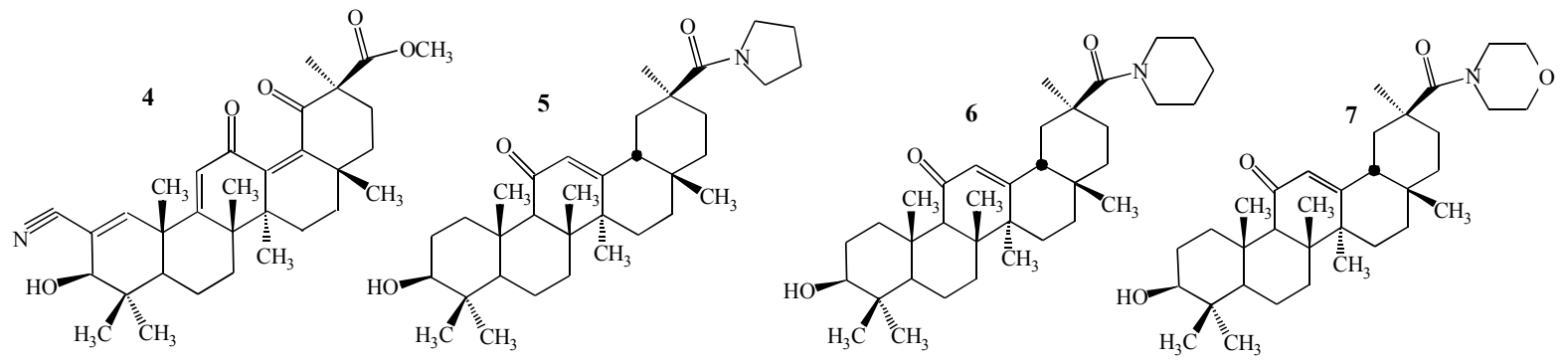

Fig. 1. Structural formulas of new derivatives (see Table)

As whole, GA and its derivatives are inefficient inhibitors of PAR synthesis catalyzed by both PARPs. GA and 7 (morpholine amide of GA) displayed somewhat better inhibition of PARP2 activity.

Influence of GA derivatives on DNA polymerase $\beta$ activity. Pol $\beta$ is the main DNA polymerase of base excision repair proceeding via short- and long patch pathways [22-24]. The level of pol $\beta$ expression and activity is enhanced in some cancer cells $[25,26]$ that leads to its competition with more accurate replicating DNA polymerases and, as a consequent, to involvement of pol $\beta$ in extrinsic DNA repair processes, for instance nuc- noid derivatives were also shown to inhibit pol $\beta$ activity with $\mathrm{IC}_{50}$ being in micromolar range $([28,29]$ and references therein).

By and large, all known inhibitors of pol $\beta$ irrespectively of compound class have $\mathrm{IC}_{50}$ values in micromolar range $[28,29]$.

Influence of GA derivatives on APE1 activity. Human APE1 is a multifunctional enzyme. APE1 is involved in BER, which eliminates base lesions and spontaneous AP sites being the main AP site hydrolyzing enzyme of higher eukaryotes [30, 31]. APE1 expression is altered in numerous cancers [31, 32]. High level of 


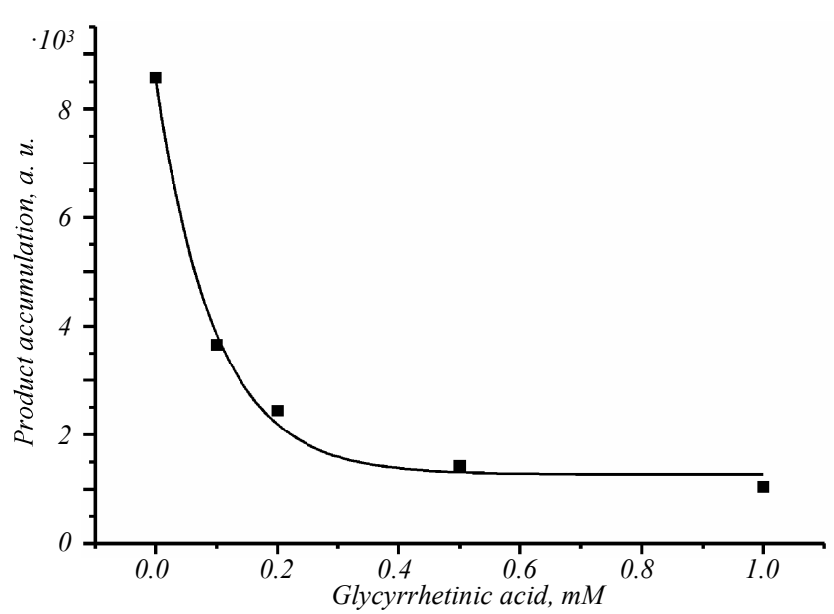

Fig. 2. Dependence of PARP2 residual activity on concentration of glycyrrhetinic acid. Concentration of PARP2 was $200 \mathrm{nM}, \mathrm{NAD}^{+}-400 \mu \mathrm{M}$

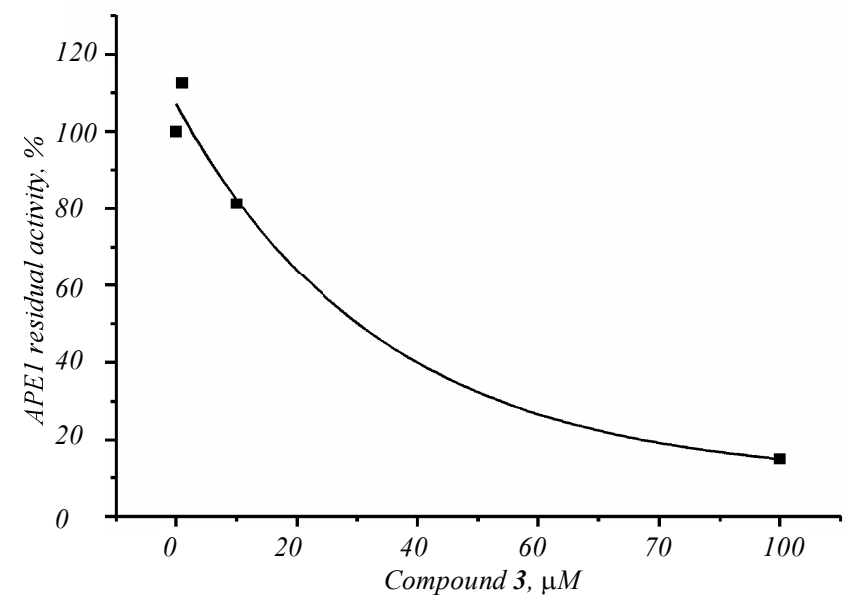

Fig. 4. Dependence of APE1 residual activity on concentration of compound 5. Concentration of AP DNA was $100 \mathrm{nM}$, APE1 - $0.3 \mathrm{nM}$

APE1 protects cells from the action of different genotoxic agents; on the contrary, suppression of APE1 leads to apoptosis and renders cells to become more sensitive to genotoxic agent exposure ([33] and references therein). Thus APE1 is considered as potential therapeutic target. Selective APE1 inhibitors can be useful both as monotherapy drugs and sensitizers in combined therapy. APE1 inhibitors have demonstrated potentiation of cytotoxicity of alkylating agents in preclinical models [31, 34-36].

Representative curve of $\mathbf{3}$ influence on APE1 activity is shown in Fig. 4. Compound 3 is the only compound, which causes practically full inhibition of APE1 activity at $100 \mu \mathrm{M}$ concentration. None of other tested compounds influences significantly the AP site hydrolysis (Table).

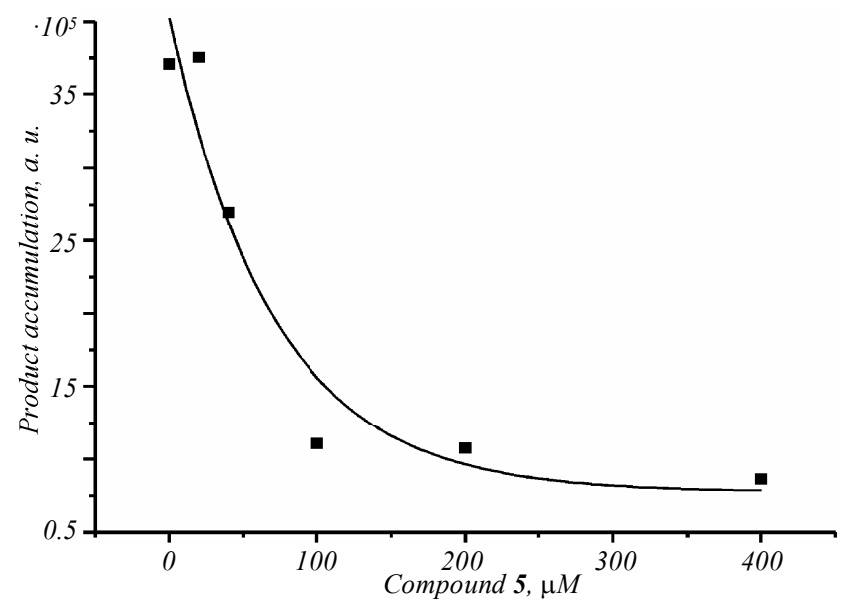

Fig. 3. Dependence of pol $\beta$ residual activity on concentration of compound 3. Concentration of pol $\beta$ was $400 \mathrm{nM}$

$\mathrm{IC}_{50}$ values of APE1 specific inhibitors discovered to date lie in the submicromolar-low micromolar range $[36,37]$.

Conclusions. The class of GA derivatives, selective pol $\beta$ inhibitors, was found out. The selective inhibitor of APE1 and weak selective inhibitor of PARP2 were also revealed.

Acknowledgments. This work was supported by the Program of Russian Academy of Sciences N 6 «Molecular and Cellular Biology» and SC N 16.512.11. 2241.

\section{А. Л. Захаренко, О. В. Саломатина, М. В. Суханова, М. М. Кутузов, С. С. Ільӥна, С. Н. Ходирева, В. Шрейбер, Н. Ф. Салахутдинов, О. І. Лаврик}

Гліциретова кислота і її похідні як інгібітори полі(АДФ-рибозо) полімераз 1 и 2, апуринової/апіримідинової ендонуклеази 1 та ДНК-полімерази $\beta$

Резюме

Мета. Щоб посилити ефективність впливу монофункціональних алкілуючих протипухлинних препаратів важливим є зниження активності системи ексиизійної репараџї основ (ЕРО), яка виправляє значну частину пошкоджень ДНК, щзо виникають за дії циих препаратів. Мета цієї роботи полягала у створенні інгібіторів ключових ферментів ЕРО (ПАРП1, ПАРП2, пол $\beta$, АРЕ1) за рахунок направленої модифікації глічиретової кислоти (ГК). Методи. Аміди ГК одержували з ацетату ГК через утворення відповідного ацилхлориду, амідування відповідним аміном з наступним деацилюванням. Невелику бібліотеку 2-ціанозаміщених метилових ефірів ГК отримано структурною модифікацією остова ГК $i$ карбоксильної групи. Інгібуючу активність сполук очінювали у відповідних специфічних тестах за присутності або відсутності сполук. Результати. Жодна з протестованих сполук не інгібує ПАРП1 значною мірою. Немодифікована ГК і ї̈ морфоліновий амід виявилися м'якими інгібіторами ПАРП2. Похідні ГК, які містять кето-групу в 11-му положенні тритерпенового остова, 
проявили помірні інгібуючі властивості стосовно пол $\beta$. Сполука

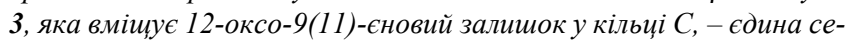
ред усіх вивчених сполук інгібує АРЕ1. Висновки. Знайдено клас сполук, селективно інгібуючих ДНК-полімеразу $\beta$. Також виявлено селективний інгібітор АРЕ1 та м'який інгібітор ПАРП2.

Ключові слова: ДНК полімераза $\beta$, полі(АДФ-рибозо)полімерази 1 i 2, апуринова/апіримідинова ендонуклеаза 1, глічиретова кислота, інгібітор.

\section{А. Л. Захаренко, О. В. Саломатина, М. В. Суханова,}

М. М. Кутузов, Е. С. Ильина, С. Н. Ходырева, В. Шрейбер,

Н. Ф. Салахутдинов, О. И. Лаврик

Глицирретовая кислота и ее производные как ингибиторы поли(АДФ-рибозо)полимераз 1 и 2, апуриновой/апиримидиновой эндонуклеазы 1 и ДНК-полимеразы $\beta$

Резюме

Цель. Для усиления эффективности влияния монофункциональных алкилирующих противоопухолевых препаратов важно снизить активность системь эксцизионной репарации оснований (ЭРО), исправляющей значительную часть повреждений ДНК, возникающих при действии этих препаратов. Целью данной работы являлось создание ингибиторов ключевых ферментов ЭРО (ПАРП1, ПАРП2, пол $\beta$, АРЕ1) за счет направленной модификациии глицирретовой кислоты (ГК). Методы. Амиды ГК получены из ацетата ГК через образование соответствующего ацилхлорида, амидирования соответствующим амином с последующим деацилированием. Небольшая библиотека 2-циианозамещченных метиловых эфиров ГК получена структурной модификацией остова ГК и карбоксильной группы. Ингибиторную активность соединений оценивали в соответствующих специфических тестах в присутствии или в отсутствие соединений. Результатыл. Ни одно из протестированных соединений не ингибирует ПАРП1 в значительной степени. Немодифичированная ГК и ее морфолиновый амид оказались мягкими ингибиторами ПАРП2. Производные ГК, содержащие кето-группу в 11-м положении тритерпенового остова, проявили умеренные ингибирующие свойства в отношении пол $\beta$. Соединение 3, содержащее 12-оксо-9(11)-еновый остаток в кольце $C$, - единственное среди всех изученных соединений ингибирует АРE1. Выводы. Обнаружен класс соединений, селективно ингибируюших ДНК-полимеразу $\beta$. Также выявлены селективный ингибитор АРЕ1 и мягкий ингибитор ПАРП2.

Ключевые слова: ДНК полимераза $\beta$, поли(АДФ-рибозо)полимеразы 1 и 2, апуриновая/апиримидиновая эндонуклеаза 1, глицирретовая кислота, ингибитор.

\section{REFERENCES}

1. Kaina B., Christmann M., Naumann S., Roos W. P. MGMT: key node in the battle against genotoxicity, carcinogenicity and apoptosis induced by alkylating agents // DNA Repair (Amst).2007.-6, N 8.-P. 1079-1099.

2. Boehler C., Gauthier L., Yelamos J., Noll A., Schreiber V., Dantzer $F$. Phenotypic characterization of Parp-1 and Parp-2 deficient mice and cells // Methods Mol. Biol.-2011.-780.-P. 313-336.

3. Reed A. M., Fishel M. L., Kelley M. R. Small-molecule inhibitors of proteins involved in base excision repair potentiate the anti-tumorigenic effect of existing chemotherapeutics and irradiation // Future Oncol.-2009.-5, N 5. P. 713-726.
4. Ishida S., Sakiya Y., Ishikava T., Awazu S. Pharmacokinetics of glycyrrhetic acid, a major metabolite of glycyrrhizin, in rats // Chem. Pharm. Bull. (Tokyo).-1989.-37, N 9.-P. 2509-2513.

5. Sakamoto K., Wakabayashi K. Inhibitory effect of glycyrrhetinic acid on testosterone production in rat gonads // Endocrinol. Jpn.-1988.-35, N 2.-P. 333-342.

6. Logashenko E. B., Salomatina O. V., Markov A. V., Korchagina D. V., Salakhutdinov N. F., Tolstikov G. A., Vlassov V. V., Zenkova $M$. A. Synthesis and pro-apoptotic activity of novel glycyrrhetinic acid derivatives // Chembiochem.-2011.-12, N 5.P. 784-794.

7. Chauhan D., Li G., Podar K., Hideshima T., Shringarpure R., Catley L., Mitsiades C., Munshi N., Tai Y. T., Suh N., Gribble G. W., Honda T., Schlossman R., Richardson P., Sporn M. B., Anderson $K$. C. The bortezomib/proteasome inhibitor PS-341 and triterpenoid CDDO-Im induce synergistic anti-multiple myeloma (MM) activity and overcome bortezomib resistance // Blood.2004.-103, N 8.-P. 3158-3166.

8. Pedersen I. M., Kitada S., Schimmer A., Kim Y., Zapata J. M., Charboneau L., Rassenti L., Andreeff M., Bennett F., Sporn M. B., Liotta L. D., Kipps T. J., Reed J. C. The triterpenoid CDDO induces apoptosis in refractory CLL B cells // Blood.-2002.100, N 8.-P. 2965-2972.

9. Tolstikov G. A., Baltina L. A., Grankina V. P., Kondratenko R. M., Tolstikova T. G. Solodka: bioraznoobrazie, khimiya, primenenie v meditsine (Licorice: Biodiversity, Chemistry, Application in Medicine).-Novosibirsk: Geo, 2007.-311 p.

10. Subba Rao G. S., Kondaiah P., Singh S. K., Ravanan P., Sporn M. $B$. Chemical modifications of natural triterpenes - glycyrrhetinic and boswellic acids: evaluation of their biological activity // Tetrahedron.-2008.-64, N 51.-P. 11541-11548.

11. Salomatina O. V., Logashenko E. B., Korchagina D. V., Salakhutdinov N. F., Zenkova M. A., Vlasov V. V., Tolstikov G. A. Synthesis and biological activity of novel glycyrrhetic acid derivatives // Doklady Chemistry.-2010.-430, N 2.-P. 35-38.

12. Su X., Lawrence H., Ganeshapillai D., Cruttenden A., Purohit A., Reed M. J., Vicker N., Potter B. V. Novel 18beta-glycyrrhetinic acid analogues as potent and selective inhibitors of 11 beta-hydroxysteroid dehydrogenases // Bioorg. Med. Chemistry.-2004.12, N 16. -P. 4439-4457.

13. Sukhanova M. V., Khodyreva S. N., Lavrik O. I. Poly(ADP-ribose) polymerase-1 inhibits strand-displacement synthesis of DNA catalyzed by DNA polymerase beta // Biochemistry (Mosc).2004.-69, N 5.-P. 558-568.

14. Drachkova I. A., Petruseva I. O., Safronov I. V., Zakharenko A. L., Shishkin G. V., Lavrik O. I., Khodyreva S. N. Reagents for modification of protein-nucleic acids complexes. II. Site-specific photomodification of DNA-polymerase beta complexes with primers elongated by the dCTP exo-N-substituted arylazido derivatives // Bioorg. Khim.-2001.-27, N 3.-P. 197-204.

15. Lebedeva N. A., Khodyreva S. N., Favre A., Lavrik O. I. AP endonuclease 1 has no biologically significant 3 ' $\rightarrow 5^{\prime}$-exonuclease activity // Biochem. Biophys. Res. Commun.-2003.-300, N 1.P. 182-187.

16. Ame J. C., Rolli V., Schreiber V., Niedergang C., Apiou F., Decker P., Muller S., Hoger T., Menissier-de Murcia J., de Murcia G. PARP-2, A novel mammalian DNA damage-dependent poly (ADPribose) polymerase // J. Biol. Chem.-1999.-274, N 25.-P. 17860 17868.

17. Zakharenko A. L., Sukhanova M. V., Khodyreva S. N., Novikov F. N., Stroylov V. S., Nilov D. K., Chilov G. G., Svedas V. K., Lavrik $O$. I. Improved procedure of the search for poly(ADP-ribose) polymerase-1 potential inhibitors with the use of the molecular 
docking approach // Mol. Biol. (Mosk).-2011.-45, N 3.-P. 517 521.

18. Kutuzov M. M., Ame J. C., Khodyreva S. N., Schreiber V., Lavrik. O. I. Interaction of PARP2 with DNA structures mimicking DNA repair intermediates // Biopolym. Cell.-2011.-27, N 5.P. 383-386.

19. Schreiber V., Dantzer F., Ame J. C., de Murcia G. Poly(ADP-ribose): novel functions for an old molecule // Nat. Rev. Mol. Cell Biol.-2006.-7, N 7.-P. 517-528.

20. Karlberg T., Hammarstrom M., Schutz P., Svensson L., Schuler $H$. Crystal structure of the catalytic domain of human PARP2 in complex with PARP inhibitor ABT-888 // Biochemistry.2010.-49, N 6.-P. 1056-1058.

21. Oliver A. W., Ame J. C., Roe S. M., Good V., de Murcia G., Pearl L. $H$. Crystal structure of the catalytic fragment of murine poly(ADPribose) polymerase-2 // Nucleic Acids Res.-2004.-32, N 2.P. 456-464.

22. Podlutsky A. J., Dianova I. I., Podust V. N., Bohr V. A., Dianov G. L. Human DNA polymerase beta initiates DNA synthesis during long-patch repair of reduced AP sites in DNA // EMBO J.-2001.-20, N 6.-P. 1477-1482.

23. Matsumoto Y., Kim K. Excision of deoxyribose phosphate residues by DNA polymerase beta during DNA repair // Science.1995.-269, N 5224.-P. 699-702.

24. Sobol R. W., Horton J. K., Kuhn R., Gu H., Singhal R. K., Prasad $R$., Rajewsky K., Wilson S. H. Requirement of mammalian DNA polymerase-beta in base-excision repair // Nature.-1996.-379, N 6561.-P. 183-186.

25. Gomi A., Shinoda S., Sakai R., Hirai H., Ozawa K., Masuzawa T. Elevated expression of DNA polymerase beta gene in glioma cell lines with acquired resistance to 1-(4-amino-2-methyl-5-pyrimidinyl)methyl-3-(2-chloroethyl)-3-nitrosourea // Biochem. Biophys. Res. Commun.-1996.-227, N 2.-P. 558-563.

26. Scanlon K. J., Kashani-Sabet M., Miyachi H. Differential gene expression in human cancer cells resistant to cisplatin // Cancer Invest.-1989.-7, N 6.-P. 581-587.

27. Canitrot Y., Hoffmann J. S., Calsou P., Hayakawa H., Salles B. Cazaux $C$. Nucleotide excision repair DNA synthesis by excess
DNA polymerase beta: a potential source of genetic instability in cancer cells // FASEB J.-2000.-14, N 12.-P. 1765-1774.

28. Mizushina $Y$. Specific inhibitors of mammalian DNA polymerase species // Biosci. Biotechnol. Biochem.-2009.-73, N 6.-P. 12391251.

29. Hu H. Y., Horton J. K., Gryk M. R., Prasad R., Naron J. M., Sun D. A., Hecht S. M., Wilson S. H., Mullen G. P. Identification of small molecule synthetic inhibitors of DNA polymerase beta by NMR chemical shift mapping // J. Biol. Chem.-2004.-279, N 38.-P. 39736-39744.

30. Fishel M. L., Kelley M. R. The DNA base excision repair protein Ape1/Ref-1 as a therapeutic and chemopreventive target // Mol. Aspects Med.-2007.-28, N 3-4.-P. 375-395.

31. Abbotts R., Madhusudan S. Human AP endonuclease 1 (APE1): from mechanistic insights to druggable target in cancer // Cancer Treat. Rev.-2010.-36, N 5.-P. 425-435.

32. Evans A. R., Limp-Foster M., Kelley M. R. Going Ape over Ref$1 / /$ Mutat. Res.-2000.-461, N 2.-P. 83-108.

33. Yang S., Irani K., Heffron S. E., Jurnak F., Meyskens F. L. Jr. Alterations in the expression of the apurinic/apyrimidinic endonuclease-1/redox factor-1 (APE/Ref-1) in human melanoma and identification of the therapeutic potential of resveratrol as an APE/Ref-1 inhibitor // Mol. Cancer. Ther.-2005.-4, N 12.-P. 1923-1935.

34. Zou G. M., Maitra A. Small-molecule inhibitor of the AP endonuclease 1/REF-1 E3330 inhibits pancreatic cancer cell growth and migration // Mol. Cancer Ther.-2008.-7, N 7.-P. 2012-2021.

35. Tell G., Wilson D. M. 3rd. Targeting DNA repair proteins for cancer treatment // Cell. Mol. Life Sci.-2010.-67, N 21.-P. 35693572 .

36. Simeonov A., Kulkarni A., Dorjsuren D., Jadhav A., Shen M., McNeill D. R., Austin C. P., Wilson D. M. 3rd. Identification and characterization of inhibitors of human apurinic/apyrimidinic endonuclease APE1 // PLoS One.-2009.-4, N 6.-e5740.

37. Wilson D. M. 3rd, Simeonov V. Small molecule inhibitors of DNA repair nuclease activities // Cell. Mol. Life Sci.-2010.-67, N 21.P. 3621-3631. 